\title{
Fen Bilimleri Öğretmen Adaylarının Kendi Tasarladıkları Öğretim Materyallerine İlişkin Görüş ve Değerlendirmeleri
}

\author{
Davut SARITAŞ \\ Nevşehir Hacı Bektaş Veli Üniversitesi, \\ davutsaritas@nevsehir.edu.tr, \\ ORCID: 0000-0002-5108-4801 \\ Oktay KIZKAPAN \\ Nevşehir Hacı Bektaş Veli Üniversitesi, \\ okizkapan@nevsehir.edu.tr \\ ORCID: 0000-0001-6781-9879
}

\begin{tabular}{lrr} 
Araştırma Makalesi & DOI: $10.31592 /$ aeusbed.609086 \\
\hline Geliş Tarihi: 22.08 .2019 & Revize Tarihi: 26.02 .2020 & Kabul Tarihi: 11.03 .2020
\end{tabular}

\section{Atıf Bilgisi}

Sarıtaş, D. ve Kızkapan, O. (2020). Fen bilimleri öğretmen adaylarının kendi tasarladıkları öğretim materyallerine ilişkin görüş ve değerlendirmeleri. Ahi Evran Üniversitesi Sosyal Bilimler Enstitüsü Dergisi, 6(1), $1-18$.

\section{ÖZ}

Türkiye'nin 44 farklı üniversitesinde öğrenim gören fen bilgisi eğitimi anabilimdalı dördüncü sınıfta okumakta olan 288 öğretmen adayının katılımı ile gerçekleştirilen bu tarama çalışmasının amacı öğretmen adaylarını kendi hazırladıkları öğretim materyallerine yönelik görüş ve değerlendirmelerinin belirlenmesidir. Araştırmacılar tarafindan hazırlana bir anket aracılığı ile toplanan verilerin betimsel analizinden elde edilen bulgulara göre öğretmen adayları materyallerinin tasarımı sürecinde ilgili literatürde yer alan bazı ilkeleri göz önünde bulundurmaları yanında maliyet gibi farklı ölçütleri de dikkate almışlardır. Bulgular, adayların materyallerinin özgün ve yaygın bir materyal olması bağlamındaki yaklaşımlarının farklılaştığını göstermektedir. Diğer bir farklılaşma materyallerinin derse katkısı ve derste kullanımı noktasındadır. Öğretmen adaylarının bir kısmı ders sonu tekrar, hatırlatma gibi amaçlar doğrultusunda materyallerinin kullanımı değerlendirirken, bir kısmı ise etkinlik, katılım, iletişim gibi amaçlar ile kullanılması yönünde fikir bildirmişlerdir. Sonuç olarak öğretmen adaylarının kendi tasarladıkları materyallere yönelik görüş ve değerlendirmeleri literatürde yer bulan tasarım ve materyal niteliğine ilişkin kabuller ile nispeten uyumlu olsa da materyalleri öğretim etkinliklerine entegre etme, bu konudaki farkındalıklarının ve materyallerine yönelik eleştirel değerlendirmelerinin yeterli olmadığı saptanmıştır. Bu nedenle ilgili lisans derslerinde öğretmen adaylarının materyallerini yöntem ile entegre edebilecekleri içeriklerin sağlanması önerilebilir.

Anahtar Kelimeler: Öğretim materyali, fen bilimleri öğretmen adayları, materyal değerlendirme, materyal tasarımı.

\section{Opinions and Evaluations of Pre-service Science Teachers about Teaching Materials They Designed}

\begin{abstract}
The purpose of this survey research study carried out by 288 pre-service science teachers studying in 44 different universities of Turkey is to determine the opinions and evaluations about the teaching materials they prepared. According to the findings collected through the questionnaire prepared by researchers, pre-service teachers took into consideration some principles mentioned in the literature in the design of the materials as well as the different criteria such as economics. Findings obtained in terms of authenticity of the materials show that the opinions of pre-service teachers about their material change between authentic and common material. While some of thepre-service teachers evaluated the use of materials for purposes such as repetition and reminder, some of them expressed their opinions about using them for purposes such as teaching activity, participation and communication. As a result, the pre-service teachers 'views and evaluations on their own designed materials are relatively consistent with the assumptions regarding the design and material quality in the literature, but in the context of active learning, the students' evaluations and awareness of material integration and contribution of materials into teaching activities used in the course are not sufficient. For this reason, it may be suggested to provide content in which the prospective teachers can realize the integration and harmony of materials with the method in the related undergraduate courses.

Keywords: Teaching material, pre-service science teacher, material evaluation, material design.
\end{abstract}




\section{Giriș}

Yazıl1, sözlü, görüntülü, kaydedilmiş her türlü belge veya gereç "Materyal” sözcüğü ile ifade edilmektedir (Türk Dil Kurumu [TDK], 2020). Buna göre öğretim mateyali öğretim ortamını zenginleştirmek adına kullanılan yazılı, sözlü, görüntülü, kaydedilmiş her türlü belge olarak tanımlanabilir. Öğrenme ortamının niteliği büyük ölçüde işe koşulan öğretim yöntem ve teknikleri, kullanılan öğretim materyalleri ve öğretmenlerin mesleki yeterliklerine bağlıdır (Duran ve Tufan, 2017; Smith ve Ragan, 2004; Yanpar, 2006). Başka bir ifade ile öğretmen, yöntem ve materyal üçlüsü iyi bir öğrenme ortamının ana bileşenleridir. İyi yetişmiş öğretmenlerin derse uygun yöntem ve teknikleri yine derse uygun öğretim materyalleri ile işe koşabilmeleri gerekir. Öğretim materyali kullanmanın özü, öğretme öğrenme sürecini kolaylaştırmaktır. Ancak bu materyallerin sınıfta bir dekorasyon aracı olarak değil, bireylerin nasıl öğrendiklerinin dikkate alınarak yürütüldüğü bir öğretim sürecinin amacına yönelik olarak hazırlanması gerekmektedir (Amadioha, 2009). Amaca yönelik olarak uygun bir şekilde hazırlanmış öğretim materyali, sınıf ortamında dikkat çekmek, bilgiyi iletmek, konu hakkında ipucu vermek, derse katılımı sağlamak, öğrenilenleri tekrar ermek, dönüt ve düzeltme verme ve değerlendirme yapmak gibi boyutlarda öğretim sürecine katkılar sunar (Şahin ve Y1ldirım, 2004).

Kaliteli bir öğretim materyali hazırlama öğretmen yetiştirmenin ve öğretmenlik mesleği uygulamasının önemli bir bilşenidir. Nitekim Türkiye Yükseköğretim Yeterlilikler Çerçevesinde (TYYÇ) de bu konu ele alınmış ve TYYÇ Öğretmen Yetiştirme ve Eğitim Bilimleri Temel Alanı Yeterlikleri kapsamında yer alan becerilerden birisi konu alanına ve öğrencinin gereksinimlerine uygun materyal geliştirmetir [Yüksek Öğretim Kurumu (YÖK), 2011]. Öte yandan MEB (2017) tarafından yayınlanan Öğretmenlik Mesleği Genel Yeterlikleri kapsamında mesleki beceriler kategorisinde yer alan yeterliklerinden biri olan öğrenme ortamları oluşturma yeterliği başlığı altında "kazanımlara uygun materyal hazırlar" şeklinde bir yeterlik ifadesine yer verilmiştir.

Öğretim materyal geliştirme ve kullanma becerisinin kazandırılması açısından öğretmen yetiştirme programların tarihine göz atıldığında zorunlu derslerin yer aldığı görülmektedir (YÖK, 1998; YÖK, 2007; YÖK, 2018). YÖK'ün 1997 eğitim fakülteleri yeniden yapılanmadırması lisans programları için bir dönüm noktasıdır (Özyurt, Bahar ve Nartgün, 2017). Bu tarihden itibaren farklı zamanlarda yapılan güncelemeler dikkate alındığında 1998 tarihli programda yer alan zorunlu "Öğretim Teknolojileri ve Materyal Tasarımı" dersinin içeriği şu şekilde ifade edilmektedir (YÖK, 1998, s.33);

“Çeşitli öğretim teknolojilerinin özellikleri, öğretim sürecindeki yeri ve kullanımı, öğretim teknolojileri yoluyla öğretim materyallerinin (çalışma yaprakları, saydanılar, slaytlar, video, bilgisayar temelli ders materyali, vd.) geliştirilmesi ve çeşitli nitelikteki materyallerin değerlendirilmesi."

2007 tarihinde güncellenen programda ise, aynı isimli dersin içeriğinin zengileştirildiği görülmektedir (YÖK, 2007, s.64);

“Öğretim Teknolojisi ile ilgili kavramlar, çeşitli öğretim teknolojilerinin özellikleri, öğretim teknolojilerinin öğretim sürecindeki yeri ve kullanımı, okulun ya da sınıfın teknoloji ihtiyaçlarının belirlenmesi, uygun teknoloji planlamasının yapılması ve yürütülmesi, öğretim teknolojileri yoluyla iki ve üç boyutlu materyaller geliştirilmesi öğretim gereçlerinin geliştirilmesi (çalışma yaprakları, etkinlik tasarlama, tepegöz saydamları, slaytlar, görsel medya (VCD, DVD) gereçleri, bilgisayar temelli gereçler), eğitim yazılımlarının incelenmesi, çeşitli nitelikteki öğretim gereçlerinin değerlendirilmesi, İnternet ve uzaktan eğitim, görsel tasarım ilkeleri, öğretim materyallerinin etkinlik durumuna ilişkin araştırmalar, Türkiye'de ve dünyada öğretim teknolojilerinin kullanım durumu" (YÖK, 2007).

2018 yılında yayınlanan son programda belirgin bir değişim görülmektedir. Bu programda zorunlu dersin ismi ve içeriği değişmiştir. "Öğretim Teknolojileri" olarak isimlendirlen dersin içeriği ise şu şekildedir (YÖK, 2018, s.9); 
“Eğitimde bilgi teknolojileri; öğretim süreci ve öğretim teknolojilerinin sınıflandırılması, öğretim teknolojilerine ilişkin kuramsal yaklaşımlar; öğrenme yaklaşımlarında yeni yönelimler, güncel okuryazarlıklar; araç ve materyal olarak öğretim teknolojileri, öğretim materyallerinin tasarımı; tematik öğretim materyali tasarlama, alana özgü nesne ambarı oluşturma, öğretim materyali değerlendirme ölçütleri”

$\mathrm{Bu}$ ders ile öğretmen adaylarına çeşitli öğretim teknolojileri ve materyallerini, bu materyallerin karakteristik özelliklerini ve bu materyallerin nasıl değerlendirileceği gibi bilgi ve becerilerin kazandırılması amaçlanmaktadır (Özcan ve Koştur, 2019).

Diğer yandan güncel programda yine öğretim materyallerine yönelik seçmeli alan eğitimi dersi olan "Fen Öğretiminde Materyal Tasarımı" dersine de yer verildiği görülmektedir (YÖK, 2018, s.24);

\begin{abstract}
“Öğretim teknolojilerinin öğretim sürecindeki yeri ve kullanımı, uygun teknoloji planlamasının yapılması ve yürütülmesi, öğretim materyalinin seçimi, materyallerin tasarım ve geliştirme ilkeleri, tasarım öğeleri, ders materyali geliştirme, öğretim teknolojileri yoluyla iki ve üç boyutlu materyaller geliştirilmesi; teknolojik pedagojik alan bilgisi, alana özgü teknolojik araç-gereçler ve materyaller (simülasyonlar, animasyonlar, sanal sınıf ve laboratuvar ortamları, kavram karikatürleri, bilimsel ölçüm yapan araçlar, çalışma yaprakları, slaytlar, görsel medya gereçleri vb.) ile fen eğitiminde kullanılabilecek diğer bilişim teknolojileri (web 2.0 araçları, mobil uygulamalar, öğrenci yanıtlama sistemleri, öğrenme yönetim sistemleri, artırılmış gerçeklik uygulamaları, ölçme ve değerlendirme araçları vb.); teknolojinin entegre edildiği sınıf ortamları, etkileşimli tahta ve eğitim portalları; fen öğretiminde alana özgü bilişim teknolojilerini kullanma ve geliştirme".
\end{abstract}

Genel olarak lisans programlarında yer alan ilgili derslerin içerikleri incelendiğinde, tarihsel süreçte zamanla zenginleştiği görülmekle birlikte, öğretmen adaylarının alana özgü materyal tasarlama, şeçme, kullanma, değerlendirme gibi açılardan bilgi ve becerilerinin geliştirilmesinin amaçlandığ1 görülmektedir. Diğer yandan literatürde öğretim teknolojileri ve materyal tasarımı üzerine çok sayıda araştırma yapıldığı görülmektedir (Cabı ve Ergün, 2016; Çalışoğlu, 2015; Duman, 2013; Özbay ve Sarıca, 2019; Özcan ve Koştur, 2019; Özer ve Tunca, 2014; Yanpar, Koray, Parmaksız ve Arslan, 2006, Yelken, 2009). Materyal tasarımı ve öğretimde materyal kullanımı ile ilgili bu çalışmalar incelendiğinde, öğretmenlerin eğitim araçlarını kullanırken bu materyallerin, öğretim hedeflerine, öğretim yöntemlerine, öğrencilerin özelliklerine, öğretim ortamına uygunluğunu göz önünde bulundurmaları gerektiği anlaşılmaktadır (Yalın, 2004).

Öğretim ortamında kullanılan materyallerin faydalarının (öğrenmeyi kolaylaştırma, istek ve tutumu artırma, aktif öğrenme sağlama, gerçek yaşamdan öğrenme deneyimleri sağlama, bireysel öğrenmeyi desteklediği, problem çözme, yaratıcılık ve eleştirel düşünme becerilerini geliştirme gibi.) akademik olarak birçok çalışma ile ortaya konulduğunu ifade eden meta analiz (Kablan, Topan ve Erkan, 2013) sonuçlarına göre, materyal kullanımı ile ilgili en fazla çalışma yapılan ve en etkili sonuçlar alınan alanların başında fen eğitimi gelmektedir. Buna karşın gerçek öğretim ortamlarında bazı sorunların devam ettiği de görülmektedir. Örneğin öğretmenlerin, öğretim programının uygulanmasındaki aksaklıkların nedenlerinden birsi olarak araç, malzeme ve materyal eksikliğini görüdükleri bildirilmekle birlikte, diğer yandan öğretmenlerin öğretim materyali kullanmada isteksiz davranabildikleri veya bu konuyu yeterince gündemlerine almadıkları, bu yönde çaba göstermedikleri de ifade edilmektedir (Fidan, 2008; Karamustafaoğlu, 2006; Kazu ve Yeşilyurt, 2008)

Eğitim fakültelerinde verilen ilgili dersin öğretmen adaylarının materyal kullanma becerilerini geliştirdiğine ilişkin yapılan çalışmalar (Bektaş, Nalçacı ve Ercoşkun, 2009; Bozpolat ve Arslan, 2018; Gömleksiz, Kan ve Serhatlığlu, 2010; Güven, 2006; Saka ve Saka, 2005) ve materyal kullanımına yönelik öz yeterliliklerinin yüksek olduğuna yönelik bulgular (Korkmaz, 2011) dikkate alındığında, meslek hayatında baş gösteren bu sorunların gözden kaçan farklı unsurlardan kaynaklanması olasıdır. Burada bir tutum ve farkındalık sorunu olduğu söylenebilir. Nitekim öğretmenlerin materyal kullanmada istekliliği materyalin faydasına olan inançlarına bağlıdır (Yalın, 2004). Ayrıca öğretmenlerin (geliştirdikleri veya hazır kullandıkları) materyallerin güçlü ve zayıf yönlerini tanımaları, bu materyali sınıf ortamında kullanmalarını kolaylaştıracaktır (Şahin ve Yıldırım, 2004). 
Diğer yandan öğretmenlerin materyallerini program içeriğine uygun hale getirmek için yapmaları gerekenlerin başında öğretim materyallerine yönelik eleştirel değerlendirmeleridir (Davis, 2006). Bu nedenle öğretmenlerin veya öğretmen adaylarının materyaller kullanmadaki olası sorunlarını aşmaları için; öncelikle materyallerinin faydalı olup olmadığına karar vermeleri, program uygun olup olmadığına karar vermeleri, başka bir ifade ile materyallerinde yönelik farkındalıkları olması gerekir. Bunun için ise güçlü, zayıf yönleri ile tanımlarına imkân verecek şekilde onlara yönelik eleştirel bir değerlendirme yapmaları önemlidir. Nitekim gerek yeni gerekse eski lisans programında yer verilen ilgili derslerle hedeflenen içerikler arasında materyal değerlendirme bilgi ve becerileri de vardır (YÖK, 1997; YÖK, 2007; YÖK, 2018).

Dolayısıyla öğretmen adaylarının öğretim teknolojileri ve materyal tasarımı dersinde hazırlamış oldukları materyallere ilişkin eleştirel görüşlerine yönelik çalışmalar önemli ve gereklidir. Alan yazın bu açıdan incelendiğinde fen öğretmenleri veya adaylarının görüşlerinin belirlenmesine yönelik çalışmaların (Akpınar, Aktamış ve Ergin, 2005; Çiftçi, Yıldız ve Bozkurt, 2015; Fidan, 2008; Kahyaoğlu, 2011; Şahin, 2015) ortak özelliği öğretmenlerin veya öğretmen adaylarının genel anlamda materyal ve öğretim teknolojisi kullanım süreçlerine odaklıdır. Fen öğretmenlerinin veya adaylarının kendi materyallerine yönelik değerlendirme ve görüşlerini ortaya çıkaran bir çalışmaya rastlanamamıştır. Bu çerçeveden hareketle bu çalışmada fen bilimleri öğretmen adaylarının öğretim teknolojileri ve materyal tasarımı dersinde farklı kazanımlara yönelik olarak hazırladıkları öğretim materyallerine yönelik görüş ve değerlendirmelerini belirlemek amaçlanmıştır.

\section{Yöntem}

Araştırmada kurumların, bireylerin veya grupların belirli özelliklerini tespit edip, bilinmek istenen bir olgunun fotoğrafını çeker gibi ortaya çıkarılmasını amaçlayan araştırma deseni olarak tanımlanan nicel araştırma yöntemine ait desenlerden tarama deseni kullanılmıştır (Yıldırım ve Şimşek, 2013). Çalışmada Fen Bilimleri öğretmen adaylarının hazırladıkları öğretim materyaline ilişkin düşüncelerini belirlemek amaçlandığından tarama desen tercih edilmiştir.

\section{Evren ve Örneklem}

Tarama deseni kullanılarak yürütülen bu çalışmada Türkiye'deki eğitim fakültelerinin Fen Bilimleri Eğitimi Anabilim Dallarında dördüncü sınıfta okuyan fen bilimleri öğretmen adayları ile çalışılmıştır. Çalışmanın verileri birinci araştırmacının yürütücü olduğu, ikinci araştırmacının ise eğitmen olarak görev aldığı ve TÜBİTAK tarafından 2237-A Bilimsel Eğitim Etkinlikleri Desteği Programı kapsamında desteklenen "Fen Öğretiminde Yöntem-Materyal Uyumu ve Entegrasyonu" isimli etkinliğe başvuran öğretmen adaylarından internet üzerinden toplanmıştır. Etkinlik kapsamında eğitim verilmek üzere Fen Bilimleri Öğretmenliği dördüncü sınıfta okuyan ve daha önce öğretim teknolojileri ve materyal tasarımı dersini almış ve bu derste en az bir materyal hazırlamış olan öğretmen adaylarının başvuruları kabul edilmiştir. Bu kapsamda Türkiye'nin tüm coğrafi bölgelerinden 44 farklı devlet üniversitesinde okuyan toplam 288 öğrenci başvuru yapmıştır. Dolayısıyla çalışmanın hedef evreni Türkiye'deki tüm Fen Bilimleri Öğretmenliği programında okuyan ve daha önce öğretim teknolojileri ve materyal tasarımı dersini almış ve bu derste en az bir materyal hazırlamış dördüncü sınıf öğretmen adayları, ulaşılabilir evren ise hedef evren içerisindeki üniversitelerden 44 tanesinde okuyan söz konusu nitelikdeki öğretmen adaylarıdır. Genelleme bu ulaşılabilir evrene yapılacaktır. Çalışmanın örneklemi ise tabakalı örnekleme yöntemi kullanılarak belirlenmiştir. Tabakalı örnekleme evrenin alt tabakalara bölünerek örneklemin her bir tabakadan ayrı ayrı ve birbirinden bağımsız olarak seçildiği örnekleme yöntemidir (Büyüköztürk vd., 2014). Örneklemde ulaşılabilir evrendeki üniversitelerin tamamını temsil edecek şekilde öğretmen adayları seçildiği için tabakalı örnekleme yöntemi kullanılmıştır.

Belirlenen örneklemde 44 farklı üniversiteden toplam 288 fen bilimleri öğretmen adayı yer almıştır. $\mathrm{Bu}$ öğretmen adaylarının 245'i $(\% 85,1)$ kadın, 43'ü $(\% 14,9)$ ise erkektir. Öğretmen adaylarının ağırlıklı not ortalamaları incelendiğinde ise ortalamaların 2,00 ile 3,76 arasında değişmekte olduğu görülmüştür. Çalışmanın verileri 2018/2019 eğitim-öğretim yılı güz döneminde 
toplanmıştır. Bu dönemde Öğretim Teknolojileri ve Materyal Tasarımı dersinin ismi değiştirilerek Öğretim Teknolojileri yapılmıştır. Ancak çalışmanın örneklemindeki öğrenciler dördüncü sınıf fen bilimleri öğretmen adayları oldukları için yapılan değiş̧iklikten etkilenmemiş ve Öğretim Teknolojileri ve Materyal Tasarımı isimli eski programın dersini almışlardır. Bu sebeple çalışmada dersin adı “Öğretim Teknolojileri ve Materyal Tasarımı” olarak kullanılmıştır.

\section{Veri Toplama Aracı}

Araştırmanın verileri araştırmacılar tarafindan hazırlanan bir anket ile toplanmıştır. Anketler belirli bir gruba ilişkin sistematik bilgi toplamak için sosyal bilim çalışmalarında çokça kullanılan toplama araçlarından biridir (Scheuren, 2004). Çalışmada kullanılan ankette katılımcıların hazırladıkları materyallerine ilişkin sorular yer almıştır. Bu kapsamda ankette katılımcılara materyallerini planlama aşamasında neleri dikkate aldıklanı, materyali üretirken nelere dikkat ettikleri, materyallerinin niteliği, materyalin derse katkıları, materyallerinin derste nasıl kullanılabileceği ve materyallerinin başka ders ve konularda kullanılabilirliği ile ilgili sorular sorulmuş ve bu sorularla ilgili bazı olası cevaplardan seçim yapmaları istenmiştir. Ayrıca katılımcıların verilen alternatif cevap seçenekleri arasından birden fazla seçim yapmalarına izin verildiği gibi bu alternatiflerin dışında "diğer" seçeneği ile açık uçlu biçimde farklı cevaplar vermelerine de izin verilmiştir. Literatürde materyal geliştirme odaklı ögretim tasarımına uygun olarak belli modeller ifade edilmekle birlikte (Karamete ve Yaşar,2018; Kızılaslan ve Sözbilir, 2017; Özerbaş ve Kaya, 2017) katılımcıların materyallerini geliştirdikleri ders içeriğinin tam anlamı ile bir öğretim tasarımı sürecini içermemesi nedeni ile soruların hazırlanmasında materyal geliştirme sürecini kapasayan boyutlar araştırmacılar tarafından belirlenmiştir. Öğretmen adaylarının materyalleri üretim sürecindeki davranışlarını hem de ürün olarak kendi materyallerine yönelik görüş ve değerlendirmelerini amaçlayan sorulara ait boyutlar şu şekilde belirlenmiştir; (1) söz konusu dersi uzun bir süredir veren (5-7 yıl) iki alan uzmanı ile yapılan görüşme ve müzakerler yapılmıştır, (2) ilgili ders için hazırlanmış olan kitaplar ve benzer çalışmalar (Kutluca ve Birgin, 2007; Şahin ve Yıldırım, 2004) incelenmiştir. 


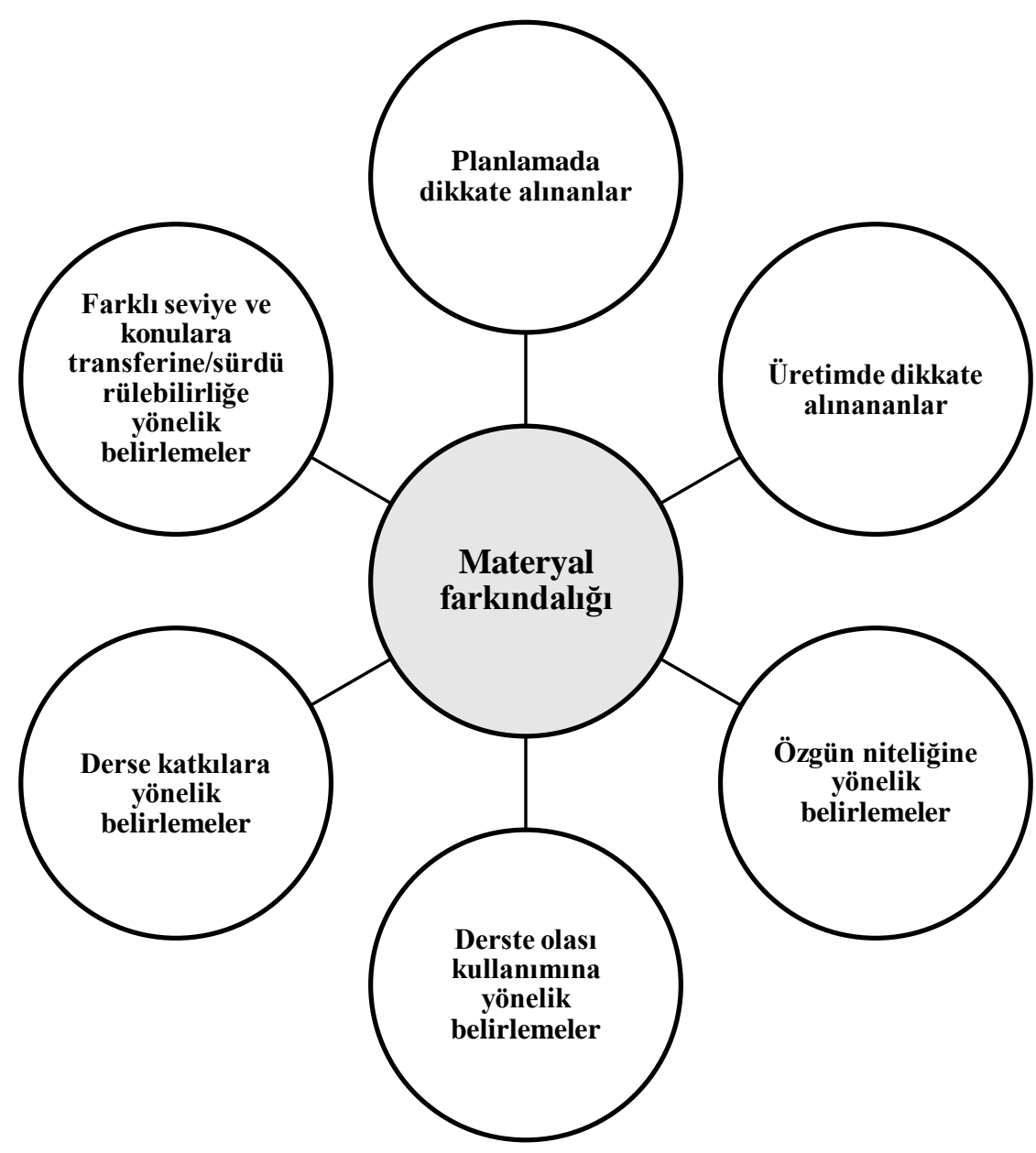

Şekil 1. Soruların Hazırlanmasında Temel Alınan Boyutlar

Veri toplama aracının hazırlanmasında problemi tanımlama, taslak formu oluşturma, uzman görüşü alma, ön uygulama son şeklini verme aşamaları dikkate alınmıştır (Büyüköztürk, 2005). Hazırlanan taslak anket formu uzman görüşüne sunulmuştur. Uzman görüşü materyal tasarımı dersi veren ve bu konuda çalışan iki alan eğitimi uzmanından alınmıştır. Uzman görüşleri doğrultusunda anket ön uygulama formu elde edilmiştir ve hedef evren dikkate alınarak bir üniversitede 47 fen bilgisi anabilimdalı dördüncü sınıfta okumakta olan öğretmen adayına uygulanmıştır. Uygulama sonunda katılımcılar ile soruların anlaşılırlığı, dili, formun biçimsel yapısı, seçeneklerin yeterliliği, soruların benzer olup olmadığ gibi sorular ile odak grup görüşmesi şeklinde cevaplayıcıların sorgulanması (Respondent Debriefining) yapılmıştır (Bolton, 1993). Uygulama sonrasında birkaç soruda bulunan ve katılımcıların açık uçlu olarak cevap vermemelerine imkân veren 'diğer' seçeneğinin tüm sorulara eklenmesi ve bazı dilsel düzenlemelerin yapılması gündeme gelmiş ve uzman görüşleri doğrultusunda yapılan bu düzenlemeler ile anket formu son halini almıştır (Ek-1). Ayrıca ön uygulamada ankette yer verilen soruların katılımcıların kendi bilinçli deneyim süreçlerine yönelik olgu ve bilgi soruları olduğu netleştiğinden herhangi bir istatistik analize ihtiyaç duyulmamıştır (Büyüköztürk, 2005). Bu çalışmada türünden bağımsız olarak hazırlanan öğretim materyallerine yönelik öğretmen adaylarının farkındalıklarını yansıtan görüş ve değerlendirilmelerinin belirlenmesi amaçlandığı için materyal türlerine ilşkin bir veri toplanmamıştır.

\section{Verilerin Analizi}

Araştırmanın verileri betimsel olarak analiz edilmiştir. Bu kapsamda araştırma sorularına katılımcıların verdikleri cevaplara ilişkin frekans (f) ve yüzde (\%) değerleri hesaplanmıştır. Araştırmada bir bağımsız değişken bulunmadığı için karşılaştırma amacıyla bir analiz yapılmamıştır. 
Öğretmen adaylarının sorulara verdikleri cevapları olabildiğince açık ve anlaşılır hale getirmek için verilere ilişkin bulgular tablolar halinde sunulmuştur.

\section{Bulgular}

Bulgular veri toplama aracında yer verilen sorulara bağlı olarak belirlenen temalar dikkate alınarak uygun başlıklar altında sunulmuştur. Her bölümde ilgili bölümdeki soruya ilişkin elde edilen veriler tablolarla verilmiştir.

\section{Planlama}

Araştırmanın bulgularından ilki öğretmen adaylarına sorulan "Materyalinizi planlama aşamasında neleri dikkate aldınız?" sorusuna verilen cevaplara ilişkindir. Öğretmen adaylarının materyallerini planlarken neleri dikkate aldıklarına dair cevaplarının dağılımı Tablo 1'de verilmiştir.

Tablo 1

Öğretmen Adaylarının Materyal Tasarlarken Dikkate Aldıkları Faktörlere Yönelik Cevapları

\begin{tabular}{lcc}
\hline Materyalinizi planlama aşamasında neleri dikkate aldınız? & Frekans (f) & Yüzde (\%) \\
\hline Öğretim programından belirli kazanımları & 251 & 34,52 \\
Sı̈ıf seviyesini & 217 & 29,84 \\
Öğretim programından belirli bir üniteyi & 123 & 16,91 \\
Ders kitabından belirli bir konuyu & 107 & 14,71 \\
Diğer (ör. "öğrenci gelişim dönemini, materyal kitaplarını") & 29 & 3,98 \\
\hline Toplam & 727 & 100 \\
\hline
\end{tabular}

Tablo 1 incelendiğinde öğretmen adaylarının ders kapsamında materyallerini planlarken en fazla ögretim programında yer alan kazanımları, ardından ise sinıf seviyesini dikkate aldıkları görülmektedir. Bunun yanı sıra öğretim materyalinin planlanmasında öğretmen adaylarınca öğretim programındaki belirli bir ünitenin ve ders kitabından belirli bir konunun daha az oranda göz önünde tutulduğu görülmektedir.

\section{Üretim}

Araştırmanın ikinci bir bulgusu öğretmen adaylarının "Materyalinizi üretirken nelere dikkat ettiniz?" sorusuna verdikleri cevaplardan oluşmuştur. Fen bilimleri öğretmen adaylarının ilgili soruya verdikleri cevapların dağılımı Tablo 2'de verilmiştir.

Tablo 2

Öğretmen Adaylarının Materyallerini Üretirken Dikkate Aldıkları Faktörlere Yönelik Cevapları

\begin{tabular}{lcc}
\hline Materyalinizi üretirken nelere dikkat ettiniz? & Frekans (f) & Yüzde (\%) \\
\hline Kolay ulaşılabilir malzemelerle yapılabilmesine & 261 & 23,51 \\
Görsel olarak uyumlu ve estetik olmasına & 242 & 21,80 \\
Dayanıklı olmasına & 220 & 19,81 \\
Maliyetinin düşük olmasına & 212 & 19,09 \\
Yapılışının kolay olmasına & 149 & 13,42 \\
Diğger (ör. "yaratıcı olması, taşınabilir olması, STEM ile uyum”) & 26 & 2,34 \\
\hline Toplam & 1110 & 100 \\
\hline
\end{tabular}

Tablo 2'ye göre öğretmen adaylarının materyallerini üretirken birbirine yakın oranda olduğu görülen belirli faktörleri dikkate almaktadırlar. Bunlar materyalin kolay ulaşılabilir malzemelerden üretilmesi, görsel uyum ve estetiklik içermesi, dayanıklllık ve düşük maliyet gibi faktörlerdir. Bunların haricinde kolay yapılabilir olma da öğretmen adayları açısından materyallerinin üretim sürecini etkileyen bir tercih faktörüdür. 


\section{Nitelik}

Araştırmada üçüncü olarak öğretmen adaylarının "Materyalinizi nasıl tanımlarsınız?" sorusu üzerinden hazırladıkları materyallerin niteliğine ilişkin değerlendirmeleri belirlenmiştir. Öğretmen adaylarının yaptıkları değerlendirmelerden elde edilen bulgular Tablo 3 ’te verilmiştir.

Tablo 3

Öğretmen Adaylarının Materyallerinin Niteliğine Yönelik Cevapları

\begin{tabular}{lcc}
\hline Materyalinizi nasıl tanımlarsınız? & Frekans (f) & Yüzde (\%) \\
\hline Özgün bir materyaldir & 161 & 40,14 \\
Bilinen bir materyalin geliştirilmiş halidir & 135 & 33,66 \\
Bilinen ve yaygın olarak kullanılan bir materyaldir & 95 & 23,69 \\
Diğer (ör. "bilinen iki materyalin birleşimidir, bir sentez materyaldir”) & 10 & 2,49 \\
\hline Toplam & 401 & 100 \\
\hline
\end{tabular}

Tablo 3 incelendiğinde, öğretmen adaylarının büyük çoğunluğunun hazırladıkları materyalleri bilinen materyallerle ilişkili olarak değerlendirdikleri görülmektedir. Bunlardan bir kısmı kendi materyallerini bilinen bir materyalin geliştirilmiş hali olarak görürken, diğer bir kısmı bilinen bir materyallerin bir kopyası olduğunu ifade etmişlerdir. Diğer yandan öğretmen adaylarının azımsanmayacak bir kısmının ise kendi materyallerini daha önce yapılmamış, özgün öğretim materyalleri olarak değerlendirdikleri görülmektedir

\section{Derse Katkı}

Araştırmada bir diğer bulgu, öğretmen adaylarının "Materyalinizin öğretim sürecinde derse nasıl bir katk1 sunmasını bekliyorsunuz?" sorusu üzerinden hazırladıkları materyallerinin sınıf ortamında ne tür katkılar sunabileceğine ilişkin değerlendirmeleri belirlenmiştir. Katılımcıların değerlendirmelerini içeren cevaplarının dağılımı Tablo 4'te verilmiştir.

Tablo 4

Öğretmen Adaylarının Materyallerinin Sınıf Ortamında Getireceği Katkılara Yönelik Cevapları

\begin{tabular}{lcc}
\hline $\begin{array}{l}\text { Materyalinizin öğretim sürecinde derse nasıl bir katkı sunmasını } \\
\text { bekliyorsunuz? }\end{array}$ & Frekans (f) & Yüzde (\%) \\
\hline Eğlenerek öğrenmeyi sağlar & 60 & 20,83 \\
Öğrenilenlerin pekiştirilmesini sağlar & 51 & 17,71 \\
Bir etkinlik içinde öğrenme imkânı sağlar & 41 & 14,24 \\
İlgi çeker & 39 & 13,54 \\
Diğer (ör. "öğretmenin işini kolaylaştırır, zamandan tasarruf sağlar”) & 27 & 9,38 \\
Dersin mesajını uygun bir şekilde iletir & 26 & 9,03 \\
Derse katılımı sağlar & 18 & 6,25 \\
Öğrenilenlerin tekrar edilmesini sağlar & 11 & 3,82 \\
Öğrenciler arasında iletişimi artırır & 8 & 2,78 \\
Yanıtsız & 7 & 2,43 \\
\hline Toplam & 288 & 100 \\
\hline
\end{tabular}

Tablo 4 incelendiğinde öğretmen adaylarının materyallerinin derse yapabileceği katkılara yönelik değerlendirmelerinin çok çeşitli olduğu görülmektedir. Bunlardan öne çıkanlar ĕglenerek öğrenmeye ve ögrenilenleri pekiştirmeye yönelik katklları ifade eden değerlendirmelerdir. Öğretmen adaylarının yine kayda değer bir kısmı hazırladıkları materyallerin bir etkinlik içerisinde ögrenme imkânı sağladı̆̆ııı düşündüklerini belirtmişlerdir. Bunları takip eden diğer değerlendirmeler ise oranına göre; materyalin ilgi çekmesi, dersin mesajlarını uygun bir şekilde iletmesi, derse katılımı sağlaması, ögrenilenlerin tekrar edilmesini sağlamsı ve ögrenciler arası etkileşimi artırmasıdır. Bunlardan altısı yeni bilgilerin öğrenme sürecine diğer ikisi ise bu bilgilerin tekrarına (öğrenilenleri tekrar etme ve pekiştirme), başka bir ifade ile ders sonuna vurgu yapan cevaplardır. 


\section{Derste Kullanım}

Diğer bir bulgu ise "Materyallerinizin gerçek sınıf ortamında nasıl kullanılması uygun olur?" sorusu üzerinden öğretmen adaylarının hazırladıkları materyalin gerçek sınıf ortamında nasıl kullanılabileceğine ilişkin değerlendirmeleri belirlenmiştir. Katılımcıların ilgili soruya verdikleri cevapların dağılımı Tablo 5'te verilmiştir.

\section{Tablo 5}

Öğretmen Adaylarının Materyallerini Gerçek Sınıf Ortamında Nasıl Kullanabileceklerine İlişkin Görüşleri

\begin{tabular}{lcc}
\hline Materyallerinizin gerçek sınıf ortamında nasıl kullanılması uygun olur? & Frekans (f) & Yüzde (\%) \\
\hline Dersin içerisinde bir etkinlik sürecinde & 98 & 34,02 \\
Dersin içinde görselliği artırma amacıyla & 68 & 23,61 \\
Dersin başında dikkat çekme amacıyla & 52 & 18,05 \\
Dersin sonunda tekrar ve pekiştirme amacıyla & 45 & 15,62 \\
Dersin sonunda değerlendirme amacıyla & 13 & 4,51 \\
Diğer (ör. "hazırbulunuşluğu ölçmek için, öğrencilere soru sormak") & 8 & 2,77 \\
Yanıssz & 4 & 1,38 \\
\hline Toplam & 288 & 100,00 \\
\hline
\end{tabular}

Tablo 5 incelendiğinde öğretmen adaylarının en fazla tercih ettikleri değerlendirme hazırladıkları materyalin ders içerisindeki etkinliklerde kullanılacağına yöneliktir. Ayrıca dersin içerisinde görselliği artırma, dersin başında dikkat çekme de sıkça tercih edilen değerlendirmedir. Diğer yandan ders süreci yerine ders sonuna vurgu yapan; materyalin dersin sonunda tekrar ve pekiştirme amacıyla kullanılması ve materyalin ders sonunda değerlendirme amacıyla kullanılmasına yönelik değerlendirmeleri olan öğretmen adayları da vardır.

\section{Transfer ve Sürdürülebilirlik}

Araştırmanın son bulgusu ise "Materyalinizin farklı konu ve sınıflarda kullanılabilirliğini nasıl değerlendiriyorsunuz?" sorusu üzerinden belirlenen değerlendirmeler oluşturmaktadır. Öğretmen adaylarının bu soruya yönelik verdikleri cevapların dağılımı Tablo 6'da gösterilmiştir.

Tablo 6

Öğretmen Adaylarının Materyallerinin Farklı Sınıf Seviyesi ve Konularda Kullanılabilirliğine İlişkin Cevaplarl

\begin{tabular}{lll}
\hline Materyalinizin farklı konu ve sınıflarda kullanılabilirliğini nasıl & Frekans (f) & Yüzde (\%)
\end{tabular}

değerlendiriyorsunuz?

Bazı değișiklikler yapılarak geliştirilebilir $\quad 27,62$

$\begin{array}{lll}\text { Başka bir sınıf seviyesinde benzer bir konuda bu hali ile kullanılabilir } & 77 & 26,92\end{array}$

$\begin{array}{lll}\text { Bazı değişiklikler yapılarak farklı bir sınıf seviyesinde kullanılabilir } & 69 & 24,12\end{array}$

$\begin{array}{lll}\text { Bazı değişiklikler yapılarak başka konularda kullanılabilir } & 35 & 12,23\end{array}$

Başka bir konuda bu hali ile kullanılabilir $\quad 14 \quad 4,89$

Diğer (ör. "5. sınıftan sonraki sınıflarda kullanılabilir, kullanılamaz") $\quad 12 \quad 4,19$

Yanitsiz

$2 \quad 0,69$

Toplam

286

100

Tablo 6 incelendiğinde öğretmen adaylarının üç değerlendirmesin yakın oranlarda öne çıktığı ve toplamın büyük bir kısmını oluşturduğu görülmektedir. Bunlar; materyallerinin bazı değişiklikler yapılarak gelişstirilebileceğini, başka bir sını seviyesinde benzer bir konuda bu hali ile kullanılabileceğini ve bazı değişiklikler yapılarak farklı bir sinıf seviyesinde kullanılabileceğine yönelik değerlendirmelerdir. Yine öğretmen adaylarının bir nispeten az bir kısmı ise bazı değişiklikler yapılarak başka konularda kullanabileceğini ve mevcut haliyle başka bir konuda kullanılabileceğini belirtmişlerdir. Değerlendirmelerin geneli hazırlanan materyalin başka sınıf seviyesi ve konuya değiştirilerek transfer edilebileceği ve bu açıdan sürdürülebilir olduğu yönündedir. 
Elde edilen bulgular iki başlıkta şu şeklide özetlenebilir;

Öğretmen adaylarının materyallerini geliştirme süreçlerine yönelik değerlendirmeleri; bulgulara göre öğretmen adayları materyallerini planlarken başta içerik kazanımları olmak üzere öğretim programını dikkate almaktadırlar (Tablo 1; \%51). Ayrıca ders kitabı da yaklaşımlarında belirleyicidir (Tablo1; \%30). Diğer taraftan materyal geliştirme sürecinde öğretmen adaylarının tercihlerini etkileyen ana etkenin ekonomik olmasına yönelik tercihlerdir (ulaşılabilir malzeme seçimi ve maliyet) (Tablo 2; \%42). Ayrıca dayanıklılık, tasarım ve hazırlamada kolaylık da faktörleri de belirleyicidir (Tablo2; \%22, \%20 ve \%13). Ancak öğretmen adaylarının sadece \%34'ün doğrudan kazanımlara gönderme yapması farklı bir açıdan öğretim programının öğretim materyalleri üzerinde belirleyiciliğine yönelik farkındalıklarının düşük olduğuna da işaret olarak yorumlanabilir.

Öğretmen adaylarının bir ürün olarak materyallerine yönelik değerlendirmeleri; bulgulara göre materyallerin derse katısı noktasında çok farklı değerlendirmeler olmasına rağmen ciddi bir oranda öğrenilenlerin tekrarı ve pekiştirilmesi odağında ders sonuna vurgular vardır (Tablo 4; \%22) yine eğlenerek öğrenme ilgi çekme ve etkinliğe imkân verme gibi ders sürecinde vurgu yapan değerlendirmeler de öne çıkmaktadır. Materyalin kullanıma yönelik olarak yapılan değerlendirmelerin ise $\% 21$ 'lik kısmı yine ders sonu vurgusu içermekle birlikte ders sürecinde etkinliğe vurgu oranı $\% 35$ civarındadır. Materyallerin sürdürülebilirliği ile ilgili materyalin değiştirilmeden kullanılmasına yönelik vurgular \%32 civarında iken, geliştirilebilir olduğunu değerlendirenler kalan kısmı oluşturmaktadır. Diğer yandan öğretmen adayları büyük bir kısmı kendi materyallerini mevcut bir materyaller ile ilişikli değerlendirmekte (Tablo 3; \%58), yine büyük bir kısmı özgünlügüne vurgu yapmaktadır (Tablo 3; \%40).

\section{Sonuç, Tartışma ve Öneriler}

Türkiye'nin farklı illerinden Öğretim Teknolojileri ve Materyal Tasarımı dersi almış ve bu ders kapsamında materyal hazırlanmış ancak daha önce gerçek bir öğretim ortamında kullanmamış Fen Bilimleri öğretmen adaylarının kendi materyallerine yönelik görüş ve değerlendirmelerini ortaya çıkarmayı amaçlayan bu çalışmadan elde edilen sonuçlar iki açıdan değerlendirilebilir. Birincisi öğretmen adaylarının materyallerini geliştirme süreçlerine yönelik kişisel yaklaşımlarına ilişkin bulgulara göre öğretmen adaylarının tercihlerinin literatürde farklı şekillerde belirtilen (Şahin ve Yıldırım, 2004); dersin ve konun hedeflerine uygunluk, dayanıklılık, görsel özellikler ve tasarım öğelerinin uyumu gibi bazı ilkelere uygun olduğu görülmekle birlikte, ilgili literatürde pek yer verilemeyen "ekonomiklik" gibi bir faktörün büyük oranda önemsedikleri görülmektedir. Diğer yandan öğretim programının öğretim materyalleri üzerinde belirleyiciliğine yönelik farkındalıklarının düşük olması literatürde rastlanan bir durumdur. Nitekim bazı çalışma sonuçlarında öğretmenlerin ve öğretmen adaylarının öğretim teknolojileri ve materyal tasarımında öğretim programını önemine yönelik görüsslerinin beklenen seviyede olmadığı görülebilir (Gömleksiz, Kan ve Serhatlığlu, 2010; Kahyaoğlu, 2011). Oysa Öğretmenlik Mesleği Genel Yeterliklerinde ifade edilen yeterliklerinden birisi kazanımlara uygun materyal hazırlamadır (MEB, 2017).

Öğretmen adaylarının bir ürün olarak materyallerine yönelik kişisel değerlendirmelerine ilişkin bulgulardan göre materyallerin öğrenilenlerin tekrarı ve pekiştirilmesi odağında ders sonunda kullanımına yönelik tercihlerinin, öğrenciye alıştırma ve uygulama yapma imkânı sağlaması gibi bazı materyal geliştirme ilkeleri ile uyumlu olduğu görülmemektedir (Şahin ve Yıldırım, 2004). Bunun yansıra öğretim sürecine vurgu yapan değerlendirmelerin literatürde ifade edilen (İşman, 2003; Yalın,2004; Şimşek, 2002) öğretim materyali özelliklerine (ilgi çekme, katılım, iletişim, etkinliğe imkân verme, eğlenerek öğrenme vb.) uygun olduğu görülmektedir. Ancak genel anlamda materyallerin kullanımı ve derse katkısı bağlamında adaylarca yapılan ders sonu vurgusu önemli bir soruna işaret etmesi bakımından önemli görülebilir. Çünkü öğretim materyalleri fen eğitiminde yerleşik bir yaklaşım olan aktif öğrenmenin gerçekleşmesi için önemli bileşenlerden birisidir. Öğrencilerin öğrenme sürecinde aktif katılımını sağlamada kullanılan etkinliklerin yürütülmesi ögretim teknolojilerini, hazırlanan eğitimsel materyalleri kullanabilmeyi gerektirir (Sivan, Leung, Woon ve Kember, 2000). Bu açıdan materyalin ders sonunda kullanılması ders sürecinin nasıl yürütüleceği sorusunu akla getirmektedir. Bu nedenle materyal kullanmada ders sonu vurgusu öğretim 
sürecinin bir aracı olan materyallerin mahiyetine yönelik bir farkındalık sorunu olarak görülebilir. Materyallerin sürdürülebilirliği ile ilgili olarak değiştirilerek kullanılmasına yönelik vurgular öğretim materyalleri, gerektiği takdirde, kolaylıkla geliştirilebilir ve güncelleştirilebilir olması ilkesine (Şahin ve Yıldırım, 2004) uyumlu değerlendirmelerdir.

Diğer yandan öğretmen adayları büyük bir kısmı kendi materyallerininin özgünlügünü mevcut bir materyaller ile ilişikli olarak değerlendirmelerine rağmen azımsanmayacak dercede bağımsız bir özgünlüne yapılan vurgularda vardır. Nitekim ilgili yerli literatürde materyallerin özgün olması gerektiğine yönelik belli bir nitelik vurgusu olmamasına rağmen gerek eski gerekse yeni programdaki derslerin içeriğinde tasarım, geliştirme gibi kavramlar yer almaktadır (YÖK,2007; 2018). Bu açıdan kavramların göndermesi bağlamında özgünlük aranan bir özellik olabilir. Ancak yeter özellik değildir. Nitekim hazır öğretim materyallerin fen eğitiminde etkili olduğunu gösteren çalışmalara da rastlanabilir (Sarıtaş ve Polat, 2017). Bu açıdan bulgular, öğretmen adaylarının kendi materyallerini derste örtük de olsa amaçlanan bir özgünlüğü dikkate alarak geliştirdiklerini ifade ettiklerini göstermektedir.

Sonuç olarak bu çalışma öğretmen adaylarının kendi geliştirdikleri materyallerine yönelik görüş ve değerlendirmelerini fen eğitimi alan yazında öğretim materyali geliştirme ile ilgili kabuller açısından incelenmesine imkân veren sonuçlar içermektedir. Çalışmanın amaçları ve sınırları doğrultusunda öğretmen adayların görüş ve değerlendirmelerinin geliştirilen materyaller açısından haklılığına ilişkin, başka bir ifade ile materyaller ile öğretmen adaylarının öznel görüş ve değerlendirmelerin uyumuna ilişkin yorum yapmak mümkün değildir. Bu bağlamda gerçek ortamlarda materyallerini kullanmamış olmaları nedeniyle kendi materyallerini değerlendirmede yanlı davranmış olmaları da mümkündür. Ancak öğretmen adaylarının öğretim materyallerinden ve teknolojilerinden yararlanmaya dönük öz yeterlilik algıları yüksek çıkmasına rağmen (Korkmaz,2011; Sezgin, Erdoğan ve Erdoğan, 2017) meslek hayatında materyal kullanmada yaşadıkları tutum ve farkındalık eksenli sorunlar (Fidan, 2008; Karamustafaoğlu, 2006; Kazu ve Yeşilyurt, 2008) arasındaki çelişkinin görünür hale gelmesinde bu çalışma sonuçları katkı sağlayabilir.

$\mathrm{Bu}$ açidan bu çalışma geliştirilen materyallerin gerçek mahiyeti ve öğretmen adaylarının değerlendirmelerini karşılaştıran veya öğretmen adaylarının eleştirel değerlendirmelerini geçerliliğini ve haklılığını inceleyen başka çalışmalar için bir başlangıç olabilir. Bu bağlamda hem öğretmenlerin materyal kullanmada yaşadıkları söz konusu sorunların giderilmesi hem de öğretmen adaylarının materyallerini kullanma ve değerlendirme eksiklerini fark etmeleri sağlanmak için ders sürecinde daha kapsamlı çalışmalar yapılabilir. Ayrıca güncellenen programda yer alan seçmeli dersi içeriğinin fen öğretimi açısından alana özgülüŭg̈ öne çıkarması nedeniyle fen materyallerine ilişkin farkındalıklarının arıtılması için bu dersin öğretmen adaylarınca alınmasın teşvik edilmesi öğretim üyelerine tavsiye edilebilir.

\section{Kaynaklar}

Akpınar, E., Aktamış, H. ve Ergin, O. (2005). Fen Bilgisi dersinde eğitim teknolojisi kullanılmasına iliş̧in öğrenci görüşleri. The Turkish Online Journal of Educational Technology, 4(1), 93100 .

Amadioha, S. W. (2009). The importance of instructional materials in our schools: An overview. New Era Research Journal of Human, Educational and Sustainable Development, 2(3), 61-63

Bolton, R.N. (1993). Pretesting questionnaires: content analysis of respondents' concurrnet verbal protocols, Marketing Science, 12(3), 280-303

Bektaş, F., Nalçacı, A., ve Erçoşkun, H. (2009). Sınıf öğretmeni adaylarının "öğretim teknolojileri ve materyal geliştirme/tasarımı” dersinin kazanımlarına ilişkin görüşleri. Kuramsal Eğitimbilim Dergisi, 2(2), 19-31. 
Bozpolat, E. ve Arslan, A. (2018). Öğretmen adaylarının öğretim teknolojileri ve materyal tasarımı dersine ilişkin görüşleri, E-Uluslararası Eğitim Araştırmaları Dergisi, 9(3), 60-84

Büyüköztürk, Ş. (2005). Anket Geliştirme. Türk Ĕgitim Bilimleri Dergisi, 3(2), 133-151.

Büyüköztürk, Ş., Kılıç Çakmak, E., Akgün, Ö.E., Karadeniz, Ş. ve Demirel, F. (2014). Bilimsel araştırma yöntemleri (17. Baskı). Ankara: Pegem Yayınları.

Cabı, E., ve Ergün, E. (2016). Öğretim teknolojileri ve materyal tasarımı dersinin öğretmen adaylarının eğitimde teknoloji kullanımına yönelik kaygılarına etkisi. Başkent University Journal of Education, 3(1), 37-43.

Çalışoğlu, M. (2015) Sınıf öğretmeni adaylarının öğretim teknolojileri ve materyal tasarımı dersine ilişkin görüşleri. Current Research in Education, 1(1), 23-32.

Çiftçi Ş, K., Yıldız P. ve Bozkurt, E. (2015). Ortaokul matematik öğretmenlerinin materyal kullanımına ilişkin görüşleri, Eğitimde Politika Analizi, 4, ss.79-89.

Davis, E. A. 2006. Preservice elementary teachers' critique of instructional materials for science. Science Education, 90(2). 348-375.

Duman, G. B. (2013). Türkçenin yabancı dil olarak öğretiminde materyal geliştirme ve materyallerin etkin kullanımı. Ana Dili Ĕgitimi Dergisi, 1(2), 1-8.

Duran, E., ve Tufan, B. S. İlkokul Türkçe ders kitaplarında oyun ve oyuncakların kullanımı. Ahi Evran Üniversitesi Sosyal Bilimler Enstitüsü Dergisi, 3(1), 16-28.

Fidan, N., K., (2008). İlköğretimde araç gereç kullanımına ilişkin öğretmen görüşleri. Kuramsal Eğitimbilim, 1(1), 48-61

Gömleksiz, M, Kan, A., ve Serhatlıŏlu, B. (2010). Öğretim teknolojileri ve materyal geliştirme dersinin materyal hazırlama ilkelerini kazandırmadaki etkililiğine ilişkin öğretmen adaylarının görüşleri. Elektronik Sosyal Bilimler Dergisi, 9(32), 1-16.

Güven, S . (2006). Öğretim teknolojileri ve materyal geliştirme dersinin kazandırdığı yeterlikler yönünden değerlendirilmesi (İnönü Üniversitesi Eğitim Fakültesi Örneği). Türk Eğitim Bilimleri Dergisi, 4(2), 165-179.

İşman, A. (2003), Öğretim teknolojileri ve materyal geliştirme, Değişim Yayınları, İstanbul.

Kablan, Z., Topan, B., ve Erkan, B. (2013). Sınıf içi öğretimde materyal kullanımının etkililik düzeyi: Bir meta-analiz çalışması. Kuram ve Uygulamada Eğitim Bilimleri, 13(3), 1629-1644.

Kahyaoğlu, M. (2011) İlköğretim öğretmenlerinin fen ve teknoloji dersinde yeni teknolojileri kullanmaya yönelik görüşleri. Eğitim Bilimleri Araştırmaları Dergisi, 1(1), 79-96.

Karamete, A ve Yaşar, Ç. (2018). Bilgisayar Donanım Birimleri Ünitesinin Öğretimi için Materyal Tasarım1. International Journal of Computers in Education, 1 (1) , 1-13. Retrieved from https://dergipark. org.tr/en/pub/ijce/issue/38078/428660

Karamustafaoğlu, O. (2006), Fen ve Teknoloji Öğretmenlerinin Öğretim Materyallerini Kullanma Düzeyleri: Amasya İli Örneği AÜ. Bayburt Eğitim Fakültesi Dergisi, 1(1), 190-101

Kazu, H., ve Yeşilyurt, E. (2008). Öğretmenlerin öğretim araç-gereçlerini kullanım amaçları. Fırat Üniversitesi Sosyal Bilimler Dergisi, 18(2), 175-188. 
Koehler, M. J., and Mishra, P. (2009). What is technological pedagogical content knowledge? Contemporary Issues in Technology and Teacher Education, 9(1), 60-70.

Korkmaz, Ö. (2011). Öğretmen adaylarının öğretim materyallerinden yararlanmaya dönük özyeterlilik algıları. Ĕ̈itim Teknolojisi Araştırmaları Dergisi, 2(4), 1-17.

Kutluca, T., \& Birgin, O. (2007). Doğru denklemi konusunda geliştirilen bilgisayar destekli öğretim materyali hakkında matematik öğretmeni adaylarının görüşlerinin değerlendirilmesi. Gazi Eğitim Fakültesi Dergisi, 27(2), 81-97

MEB

(2017).

Öğretmenlik

Mesleği

Genel

Yeterlikleri. http://oygm.meb.gov.tr/meb_iys_dosyalar/2017_12/11115355_YYRETMENLYK_MESLEY Y_GENEL_YETERLYKLERY.pdf adresinden 31.07.2019 tarihinde erişilmiştir.

Mishra, P., and Koehler, M. (2006). Technological pedagogical content knowledge: A framework for teacher knowledge. The Teachers College Record, 108(6), 1017- 1054.

Özbay, Ö. ve Sarıca, R. (2019). Ters yüz sınıfa yönelik gerçekleştirilen çalışmaların eğilimleri: Bir sistematik alanyazın taramas1. Ahi Evran Üniversitesi Sosyal Bilimler Enstitüsü Dergisi, 5(2), 332-348.

Özcan, H., and Koştur, H. İ. (2019). Analyzing Pre-service Science Teachers' Physics Materials. Science Education International, 30(1).

Özel, E. (2012). Sosyal Bilgiler öğretmenlerinin öğretim teknolojilerine yönelik tutum ve davranışları. Doğu Coğrafya Dergisi, 19(31), 129-144.

Özer, Ö., and Tunca, N. (2014). The opinion of pre-service teachers towards preparating and using of materials. Route Educational and Social Science Journal, 1(3), 214-229.

Özerbaş, M. A. ve Kaya, A.B. (2017). Öğretim tasarımı çalışmalarının içerik analizi: ADDIE modeli örneklemi. Türk Eğitim Bilimleri Dergisi, 15(1), 26-42.

Özyurt, Y., Bahar, M. ve Nartgün, Z. (2017). Fen bilgisi öğretmenliği lisans dersleri öğrenme çıktılarının özel alan yeterlikleriyle örtüşme düzeyi. Abant İzzet Baysal Üniversitesi Eğitim Fakültesi Dergisi, 17 (4), 2096-2116.

Saka, A. Z. ve Saka, A. (2005). Öğretmen adaylarının öğretim teknolojileri ve materyal geliştirme dersinde mesleki becerilerini geliștirme düzeyi: Sakarya örneği. Sakarya Üniversitesi Ĕgitim Fakültesi Dergisi, 10, 81-177.

Sarıtaş, D. ve Polat, M. (2017). Hazır öğretim materyalleri ile bazı temel fen kavramlarına yönelik yanılgıların giderilmesi, Researcher: Social Science Studies, 5(10). 73-100.

Scheuren, F. (2004). What is a Survey?. Alexandria: American Statistical Association.

Sezgin, F., Erdoğan, O. ve Erdoğan, B.H. (2017). Öğretmenlerin teknoloji öz yeterlikleri: Öğretmen ve öğrenci görüşlerine yönelik bütüncül bir analiz, Eğitim Teknolojisi Kuram ve Uygulama 7(1), 180-200.

Kızılaslan, A ve Sözbilir, M . (2017). Görme Yetersizliği Olan Öğrencilere Yönelik Geliştirilen Fen Etkinliklerin Değerlendirilmesi: Isı ve Sıcaklık. Ege Eğitim Dergisi, 18 (2) , 914-942. DOI: 10.12984/egeefd.314586 
Shulman, L. S. (1986). Those who understand: Knowledge growth in teaching. Educational Researcher, 15(2), 4-14.

Sivan, A., Leung, R. W., Woon, C.C. and Kember, D. (2000). An implementation of active learning and its affect on quality of student learning. Inovations in Education and Training International, 37(4), 381-389.

Smith, P. L., \& Ragan, T. J. (2004). Instructional design. John Wiley \& Sons.

Şahin, M. (2015). Öğretim materyallerinin öğrenme-öğretme sürecindeki işlevine ilişkin öğretmen görüşlerinin analizi. Kastamonu Ĕ̈itim Dergisi, 23(3), 995-1012.

Şahin, T. Y., ve Yıldırım, S. (2004). Öğretim teknolojileri ve materyal geliştirme. Anı Yayıncılık.

Şimşek, N. (2002). Derste eğitim teknolojisi ve öğretim, Ankara: Kadığlu Matbaası.

Türk Dil Kurumu Sözlügü̈. (2020). "Materyel”. https://sozluk.gov.tr/

Yalın, H. İ. (2004). Öğretim Teknolojileri ve Materyal Geliştirme (13. Baskı). Ankara: Nobel Yayınc1lik.

Yanpar, T (2006). Teknoloji Tabanlı Eğitim. Sönmez (Ed). Eğitim Bilimlerine Giriş, (ss.187-212). Ankara: Anı Yayıncilik.

Yanpar, T., Koray, Ö., Parmaksız, R. Ş., ve Arslan, A. (2006). İlköğretim öğretmen adayları tarafindan hazırlanan el yapımı ve teknoloji temelli materyallerin yaratıcılık boyutlanı açısından incelenmesi. Kuram ve Uygulamada Ĕ̈itim Yönetimi, 45(45), 129-148.

Yelken, T. Y. (2009). Öğretmen adaylarının portfolyoları üzerinde grup olarak yaratıcılık temelli materyal geliştirmenin etkileri. Eğitim ve Bilim, 34(153).

Yıldırım, A., ve Şimşek, H. (2013). Sosyal bilimlerde nitel araştırma yöntemleri (9. Baskı). Ankara: Seçkin Yayıncılık.

Yüksek Öğretim Kurulu. (1998). Eğitim Fakültesi Öğretmen Yetiştirme Lisans Programı. Ankara: Yüksek Öğretim Kurulu Başkanlığı. https://www.yok.gov.tr/Documents/Yayinlar/Yayinlarimiz/egitim-fakultesi-ogretmenyetistirme-lisans-programlari-mart-1998.pdf adresinden 17.08.2019 tarihinde erişilmiştir.

Yüksek Öğretim Kurulu. (2007). Eğitim fakültesi öğretmen yetiştirme lisans programı. Ankara: Yüksek Öğretim Kurulu Başkanlığı. https://www.yok.gov.tr/Documents/Yayinlar/Yayinlarimiz/egitim-fakultesi-ogretmenyetistirme-lisans-programlari-mart-1998.pdf adresinden 17.08.2019 tarihinde erişilmiştir.

Yüksek Öğretim Kurulu. (2011). Türkiye Yükseköğretim Yeterlilikler Çerçevesi (TYYÇ) Temel Alan Yeterlilikleri: Öğretmen Yetiştirme ve Eğitim Bilimleri. http://tyyc.yok.gov.tr/?pid=48 adresinden 28.07.2019 tarihinde erişilmiştir.

Yüksek Öğretim Kurulu. (2018). Öğretmen Yetiştirme Lisans Programları (Basın Bülteni). Ankara: Yüksek Öğretim Kurulu Başkanlı̆gı. https://www.yok.gov.tr/kurumsal/idaribirimler/egitimogretim-dairesi/yeni-ogretmen-yetistirme-lisans-programları adresinden 28.07.2019 tarihinde erişilmiştir. 


\section{Extended Abstract}

\section{Introduction}

The quality of the learning environment depends largely on the teaching methods and techniques used, teaching materials and teachers' professional competencies (Smith and Ragan, 2004). Well-educated teachers should be competible to work with appropriate teaching methods and techniques. One of these pedagogical competencies is the ability to prepare and use materials appropriate to the subject area and the needs of the student. The main aim of the related courses in teacher training programs (YÖK, 1998; YÖK, 2018) is to provide the prospective teachers with various instructional technologies and materials, characteristics of these materials and how to evaluate these materials (Özcan and Koştur, 2019). The shortest way to acquire such skills is to enable prospective teachers to evaluate their own instructional materials. Examining pre-service teachers' views and assessments of their materials will not only determine whether they act according to the material development criteria, but also determine their assessment skills, awareness of their materials and, most importantly, whether they believe in the usefulness of their materials. As a matter of fact, the willingness of teachers to use material depends on their belief in the usefulness of the material (Yalın, 2004). In this context, aim of this research is to determine the opinions and evaluations of the prospective science teachers about the materials they prepared for different objectives in instructional technologies and material design course.

\section{Method}

This study was conducted using a survey design. The sample of the study was selected from senior students of science education department of education faculties in Turkey. While determining the sample of the study, criterion sampling was used as purposeful sampling methods because it was necessary to study in science education department, being in the fourth grade and took technology and material design course previously. A total of 288 senior science education students from 44 different universities in Turkey participated in the study.

The questionnaire which was used for data collection was prepared by the researchers and the stages of defining the problem, creating a draft form, getting expert opinion, and giving final form of pre-application were followed (Büyüköztürk, 2005). In the preparation of the multi-choice and openended questions in the questionnaire, ADDIE (Analysis, Desing, Development, Implementation, Evaluation) model (Özerbaş and Kaya, 2017), which is the most widely known in instructional design models and widely used in material design courses, has been taken into consideration.

\section{Result, Discussion and Conlusion}

Findings which is obtained from descriptive analyses can be summarized under two subheadings;

Personal approaches of teacher candidates in material development process; According to the findings, pre-service teachers take into account the curriculum, especially content objectives, when planning their materials (Table $1 ; 51 \%$ ). In addition, the textbook is also decisive in their approach (Table $1 ; 30 \%$ ). On the other hand, the main factors affecting the preferences of prospective teachers during the material development process are economic choices (selection of available materials and cost) (Table 2; 42\%). Durability, ease of design and preparation are also determinant factors (Table 2; $22 \%, 20 \%$ and $13 \%$ ).

Regarding the personal assessments of teacher candidates about their materials; According to the findings, although there are very different evaluations in terms of the entegration of the materials into the lesson, there is a significant emphasis on the repetition and reinforcement of the learned topics (Table $4 ; 22 \%$ ). Also, evaluations emphasizing the learning process by having fun and allowing the activity are also prominent. While $21 \%$ of the evaluations made for the use of the material also include end-of-course emphasis, the emphasis on the effectiveness of the course is around 35\%. While the emphasis on the sustainability of the materials on the use of the material as its original form is around 
$32 \%$, the rest are those who consider it to be improved. On the other hand, morethan half of the preservice teachers evaluate their own materials in relation to existing materials (Table 3; 58\%), while some of them emphasize their originality (Table 3; 40\%).

Based on the findings, it can be said that pre-service teachers' views and evaluations about their own designed materials are relatively compatible with the assumptions regarding the design and material quality in the literature (Şahin and Yıldırım, 2004 Yalın, 2004; Simşek, 2002; İşman, 2003). However, in the context of active learning, it is seen that the students are not enough to integrate the materials into the teaching activities used in the course addition and their awareness of their contribution to this point. For this reason, it may be suggested to provide content in which the prospective teachers can realize the integration and harmony of materials with the method in the related undergraduate courses. On the other hand, in line with the aims and limits of the study, it is not possible to comment on the fairness of the opinions and evaluations of the prospective teachers in terms of the developed materials; in other words, it is not possible to comment on the harmony of the prospective teachers' subjective opinions and evaluations. In this context, it is also possible that they have been biased in evaluating their own materials because they have not used their materials in real settings. However, despite the high self-efficacy of prospective teachers to benefit from instructional materials and technologies (Sezgin, Erdoğan and Erdoğan, 2017; Korkmaz,2011), the results of this study may contribute to making the contradiction between the attitude and awareness-based problems experienced in the use of materials in professional life visible (Kazu and Yeşilyurt, 2008; Karamustafaoğlu, 2006; Fidan, 2008). In this respect, this study may be a prelude to the actual nature of the materials developed and other studies comparing prospective teachers 'assessments or examining the validity and justification of prospective teachers' critical evaluations. In this context, more comprehensive studies can be carried out both to eliminate the problems experienced by teachers in using materials and to ensure that prospective teachers realize the deficiencies in using and evaluating their materials. 
Ek-1: Veri Toplamada Kullanılan Anket

\section{Demografik Özellikler}

Cinsiyet: ( ) Kadın ～( ) Erkek

Yaşadığınız İl:

Öğrenim Gördüğünüz Üniversite:

Sinıfinız: ( ) 1. Sinif （ ) 2. Sinif （ ) 3. Sinif $\quad$ ( ) 4. Sinif

Genel Not Ortalamanız:

Lisans eğitimi süresince;

( ) Materyal tasarımı dersi aldım ve materyal hazırladım.

( ) Materyal tasarımı dersi aldım ancak materyal hazırlamadım.

( ) Materyal tasarımı dersi almadım.

Anket Maddeleri

1. Materyalinizi planlama aşamasında neleri dikkate aldını? (Birden fazla seçeneği işaretleyebilirsiniz)

( ) Ders kitabından belli bir konuyu

( ) Öğretim programından belli bir üniteyi

( ) Öğretim programından belli kazanımları

( ) Sinıf seviyesini

( ) Diğer (

2. Materyalinizi üretirken nelere dikkat ettiniz? (Birden fazla seçeneği işaretleyebilirsiniz

( ) Maliyetin düşük olmasına

( ) Kolay ulaşılabilir malzemelerin kullanılmasına

( ) Yapılmasinın kolay olmasina

( ) Dayanıklı olmasına

( ) Görsel olarak uyumlu ve estetik olmasına

( ) Diğer (

3. Materyaliniz; (Birden fazla seçeneği işaretleyebilirsiniz)

( ) Bilinen ve yaygın olarak kullanılan bir materyaldir

( ) Orijinal bir materyaldir

( ) Bilinen bir materyalin geliştirilmiş halidir

( ) Diğer (

4. Gerçek sınıf ortamında materyaliniz; (Birden fazla seçeneği işaretleyebilirsiniz)

( ) Derse katılımı sağlar

( ) İlgi çeker

( ) Öğrenilenlerin pekiştirmelerini sağlar

( ) Öğrenilenlerin tekrar etmelerini sağlar

( ) Öğrencilerin kendi aralarında iletişimlerini artırır

( ) Eğlenerek öğrenmeyi sağlar

( ) Bir etkinlik içerisinde öğrenmeye imkân verir

( ) Dersin mesajlarını uygun bir şekilde iletir

( ) Diğer ( 


\section{Hazırladığınız materyal gerçek sınıf ortamında nasıl kullanılabilir? (Yalnızca birini} seçiniz)

( ) Dersin başlangıcında dikkat çekmede

( ) Dersin sonunda değerlendirmede

( ) Dersin içinde bir etkinlik sürecinde

( ) Dersin içinde ders anlatımında görselliği arttırmada

( ) Konu işlendikten sonra tekrar ve pekiştirmede

( ) Diğer (

6. Materyaliniz ile ilgili olarak; (Birden fazla seçeneği işaretleyebilirsiniz)

( ) Başka bir konuda bu hali ile kullanılabilir

( ) Başka bir sınıf seviyesinde benzer bir konuda bu hali ile kullanılabilir

( ) Bazı değişiklikler yapılarak geliştirilebilir

( ) Bazı değişiklikler yapılarak başka konularda kullanılabilir

( ) Bazı değişiklikler yapılarak farklı bir sınıf seviyesinde kullanılabilir

( ) Diğer ( 